Research.

\title{
Moderating effect of profitability on intellectual capital and real earnings management
}

\author{
Sistya Rachmawati \\ Department of Accounting, Trisakti University, Jakarta, Indonesia. \\ sistya_r@yahoo.com (S. Rachmawati)
}

Received: February 15, 2020; Accepted: March 27, 2020; Published: June 30, 2020.

To cite this article: Rachmawati, S. (2020). Moderating effect of profitability on intellectual capital and real earnings management. The Accounting Journal of BINANIAGA. 5 (1): 33-44. doi: 10.33062/ajb.v5i01.366

\begin{abstract}
This study aims to determine (1) Effect of intellectual capital, on real earnings management (2) Effect of capital employed efficiency (CEE) on real earnings management (3) Effect of structural capital efficiency (SCE) on real earnings management (4) Effect of human capital efficiency (HCE) on real earnings management (5) Profitability as a moderating variable can strengthen the effect of intellectual capital on real earnings management. Sample collection was carried out using purposive sampling and produced a sample of 80 companies during the 20152017 period which was 240 companies. The analytical tool used is multiple linear regression with the Fixed Effect method. The results of the study show that intellectual capital has a negative effect on real earnings management. Neither can profitability strengthen the effect of intellectual capital on real earnings management. Whereas the control variable which has a significant influence on real earnings management is earnings growth.
\end{abstract}

Keywords: Real Earnings Management, Profitability, Intellectual Capital

\section{BACKGROUND}

The paradigm shift of the company that was originally a business based on labor (labor-based business) towards a business that is based on knowledge (knowledgebased business). This has led to the emergence of the idea that intellectual capital is one approach in the valuation of measuring intangible assets (intangible assets) (Petty \& Guthrie, 2000). Some other examples of intangible assets include science and technology, trademarks, patents, copyrights, customer lists, relationships with suppliers and customers, customer loyalty, marketing rights, market share, import quotas, and franchises (Ulum, 2009). Intellectual capital can be used to create and apply knowledge in order to increase company value. The awareness that intellectual capital plays an important role in the company's growth, makes the company pay more attention to the management of intellectual capital. Jacub (2012) and Darbi et al (2012) measure intellectual capital introduced by Pulic (1998) by using Value Added Intellectual Coefficient (VAIC) ). The VAIC TM method is used to provide information about the value creation efficiency of tangible and intangible assets of a company. The main components of VAIC in research conducted by Pulic, (1998) are Human Capital Efficiency (HCE), Capital Employed Efficiency (CEE), and Structural Capital Efficiency (SCE).

Currently, investors will consider investing in companies that have good corporate value. With the existence of Intellectual Capital information, it can increase the value of the company. Investors assess the company's performance by looking at the financial statements made by the company. Financial statements can show management performance. The parameters used to measure performance are information about earnings (Tohir \& Yuyetta, 2013). Earnings information in this case profitability has a variety of functions including the aim to assess management performance, help in

Sistya Rachmawati. Moderating effect of profitability on intellectual capital and real earnings management 
estimating the ability of representative earnings in the long run, forecast earnings (Darabi et al., 2012).

However, investor attention sometimes only focuses on earnings information, not on the procedure of how earnings information is generated, thus giving managers the opportunity to manage earnings. The existence of agency conflict can lead to discretion so that management causes incomplete information (asymmetry information). lack of complete information (asymmetry information) can mislead users of financial statements. As research conducted by Wato (2016) shows a positive relationship of intellectual capital to real earnings management, discretionary real earnings management, CFO (cash flow from operation) real earnings management, and future stock returns. The same result was shown by Galdipour et al, (2014) that intellectual capital had a positive and significant effect on earnings management, but researchers found no evidence that intellectual capital development had an effect on earnings management.

\section{LITERATURE REVIEW AND HYPOTHESIS DEVELOPMENT}

\section{The Public Model (VAIC Method)}

Pulic, (1998) developed the design of a model to provide information about the efficiency of value creation from tangible assets and intangible assets owned by companies. In Pulic's model, the key aspect is to treat the workforce as a valuecreating entity. Pulic, (1998). The result is that VA expresses the newly created wealth of a period (Ulum, 2009).

According to Firer \& Williams (2003), the disadvantage of using the VAIC TM method in analyzing intellectual capital is that measurements are limited by circumstances when these measurements are calculated only in the internal parts of financial statements or only based on appropriate models and principles. The advantage of using the VAIC TM method in analyzing intellectual capital is that data is relatively easier to obtain from various sources and types of companies. Data needed to calculate these measurements are standard financial figures that are generally contained in the company's financial statements.

\section{Understanding Agency Theory (Agency Theory)}

Jensen \& Meckling (1976) put forward agency relationship theory because there is a contract between the manager (agent) and the investor (principal) as a joint agreement to carry out a job. The owner seeks profits by obtaining high returns and stable results continuously to maintain his company. While management is looking for profit by receiving a high bonus from the work agreement and wants to maintain it even increase it. From these differences arises a conflict between management and owner because of the desire to fulfill their respective interests (opportunistic behavioral).

\section{Real Profit Management}

Earnings management can be defined as a state when managers manipulate financial statements by using their valuations in financial statements and compiling transactions to change financial statements that aim to provide misleading information to several stakeholders regarding company performance (Healy \& Wahlen, 1999).

Galdipour et al (2014) halve the reasons for earnings management. First, political costs are considered to be able to motivate managers in smoothing earnings against reported income. Second, efficient contracting can be used as a reason for manipulating reported earnings, because shareholders can request the dismissal of managers due to low-income levels. As a result, managers manipulate income through the sale of depreciated assets, reduce the allowance for doubtful accounts, change estimates and accounting methods and others to protect the positions they 
hold. Zang (2006) states that there are various techniques for carrying out earnings management. Companies can do earnings management by manipulating real activities other than accrual-based earnings management. According to Roychowdhury (2006), real earnings management is an act of deviating management from normal business practices with the main goal of achieving the desired profit target.

\section{Profitability}

According to Hassan \& Fapouk (2014), Profitability is the company's ability to generate profits which will be the basis for dividend distribution. Profitability describes the ability of a business entity to generate profits by using all of the company's capital. This is in accordance with the statement of Shapiro, (1991): "Profitability measures measure management objectiveness as indicated by return on sales, assets and owners equity

\section{Hypothesis Development}

a. Effect of Intellectual Capital on Real Earnings Management

Disclosure of intellectual capital can meet the information needs of those who are not involved in making the report. With so many intellectual capitals in a company, it will indirectly affect market perceptions of company performance. Marzban et al (2014) conducted research on the relationship between intellectual capital and real earnings management. The result is that there is no significant relationship between intellectual capital and real earnings management. Similarly, Zanjirdar \& Chogha (2012) research concluded that there was no significant relationship between intellectual capital and real earnings management. Another case with Wato's research (2016) showed that there was a significant positive effect of VAIC on MR-CFO (Real Profit Management - Cash Flow from Operations). Wato's research (2016) shows some companies in Indonesia that use and develop intellectual capital (IC) such as professional staff (CEO, CFO, Director, Manager, etc.) to develop a company with the aim of achieving an expected profit target. Based on the description above, the hypotheses that can be formulated are:

$\mathrm{H} 1$ : Intellectual Capital has a negative effect on real earnings management

b. Effect of Capital Employed Efficiency (CEE) on Real Profit Management

Pramanda \& Husnah, (2014) found that Capital Employed Efficiency (CEE) has a positive relationship with real earnings management. These results are not in line with the study of Darabi et al (2012) which concluded that CEE has no effect on real earnings management. Mojtahedi (2013) also found that there is a positive relationship between Relationship Capital Efficiency (RCE) and real earnings management. Asset management produces an added value that can determine the value of the resulting profit. The low level of profit can affect the performance evaluation of management that is not good. This causes managers to be motivated to do real earnings management. Based on the description above, the hypotheses that can be formulated are:

H2: Capital Employed Efficiency (CEE) has a negative effect on real earnings management.

c. Effect of Structured Capital Efficiency (SCE) on real earnings management

Structured Capital Efficiency (SCE) Is a resource company that has knowledge of the company's ability to use and manage existing resources. Research (Pramanda \& Husnah, 2014) found that Structured Capital Efficiency (SCE) has a negative effect on real earnings management in line with research by Darabi et al (2012) and Mojtahedi (2013) who found a positive relationship 
between Structured Capital Efficiency (SCE) on earnings management real. Organizational ability can have a positive or negative effect on the value of a company in terms of managing structured capital with a large burden can reduce the value of its efficiency, but if the organization's ability is seen from technology and information and the quality of decision making, it can reflect quality earnings. Based on the description, the hypotheses that can be formulated are:

H3: Structural Capital Efficiency (SCE) has a negative effect on real earnings management

d. Effect of Human Capital Efficiency (HCE) on real earnings management

Each organization places intellectual material in the form of explicit and hidden assets and resources, perspectives, and abilities, data, information, knowledge, and possibly policies. Human Capital is a piece of knowledge that can provide benefits and added value to the company.

Galdipour et al (2014) in his research found that human capital has a significant negative correlation with real earnings management, where the proxy used for earnings management is accrual earnings management. Based on the description, the hypotheses that can be formulated are:

H4: Human Capital Efficiency (HCE) has a negative effect on real earnings management

e. Profitability moderates intellectual capital for real earnings management

In making a decision to invest in a company, of course, many things are considered by investors. The majority of investors make an assessment of the financial statements of a company in a certain period. In financial statements, profitability is an important concern for investors in seeing the company's financial condition. Profitability itself is an interpretation of a company's ability to get profits in relation to assets, sales or own capital.

Hassan \& Fapouk (2014) found that profitability has a significant effect on real earnings management. This shows that the higher the profitability ratio, the better the company's financial condition and the greater the real earnings management.

Profitability also cannot determine that the company can produce persistent earnings. In addition, research from Darabi et al (2012) and Mojtahedi (2013) states that intellectual capital has a positive influence on real earnings management. Based on the explanation above, the second hypothesis of this study is as follows:

H5: Profitability can strengthen the effect of intellectual capital on real earnings management.

\section{RESEARCH METHODS}

\section{Independent Variable}

The independent variable used in this study is Intellectual Capital which is measured by referring to Darabi et al., (2012) and Murwaningsari, (2014):

Capital Employed Efficiency (CEE):

$$
C E E=\frac{V A}{C E}
$$

Human Capital Efficiency (HCE) according to (Darabi et al., 2012):

Sistya Rachmawati. Moderating effect of profitability on intellectual capital and real earnings management 


$$
H C E=\frac{V A}{H C}
$$

Structural Capital Efficiency (SCE) according to (Darabi et al., 2012):

$$
S C E=\frac{S C}{V A}
$$

Value Added Intellectual Coefficient (VAIC) according to (Darabi et al., 2012):

\section{Dependent Variable}

$$
V A I C=H C E+S C E+C E E
$$

The dependent variable in this study is earnings management. Roychowdhury (2006), Rachmawati, (2019) earnings management through real activities is defined as a deviation from the normal operating activities of a company motivated by management's desire to provide a misconception to stakeholders that certain financial reporting objectives have been achieved through the company's normal operating activities. Earnings management through real activities refers to the play of profit figures carried out through activities that originate from normal business activities or those related to operational activities, for example delaying product promotion activities or accelerating sales by giving large discounts (Sulistiawan, 2011).

Abnormal CFO

CFOt / At-1 $=\alpha 0+\alpha 1(1 /$ At-1 $)+\alpha 2($ St / At-1) $+\alpha 3(\Delta S t / A t-1)+\varepsilon t$

Abnormal Discreationary Expenses

DISEXPt / At-1 = $\alpha 0+\alpha 1(1 /$ At-1) $+\alpha 2($ St-1 / At-1) $+\varepsilon t$

Abnormal Production Cost

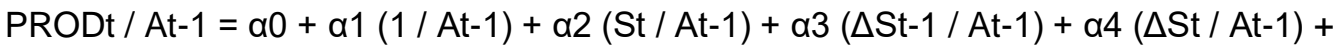
$\varepsilon t$

Real Earning Management

$R E M=\left(A B \_C F O\right)+\left(A B \_D I S E X P\right)-\left(A B \_P R O D\right)$

\section{Moderation Variable}

The moderation variable is profitability. Hassan \& Fapouk, (2014). Company profitability is one of the bases for evaluating the condition of a company. The analysis tool in question is financial ratios. Profitability ratios measure management effectiveness based on returns obtained from sales and investments "(Hassan \& Fapouk, 2014). In this study, profitability is measured by return on assets. The formula is as follows:

$$
\text { ROA }=\frac{\text { Net Profit After Tax }}{\text { Total Assets }}
$$

\section{Control Variable}

Inst_Own (Institutional Ownership) Referring to Tong, (2011):

$$
\frac{\text { Number of Institutional Stock }}{\text { Number of Outstanding Stock }} \times 100 \%
$$

Size (Company Size), Darabi et al., (2012):

$$
F A=L O G T A
$$

Sistya Rachmawati. Moderating effect of profitability on intellectual capital and real earnings management 
The Accounting Journal of BINANIAGA Vol. 05, No. 01, June 2020

p-ISSN: 2527-4309, e-ISSN: 2580-1481

$5^{\text {th }}$ Accreditation Rating: January 14, 2019 - January 13, 2024

Growth (Internal Growth Prospects)

Change in Sales

Sales of the year $\mathrm{t}-1$

Leverage (Corporate Risk), Pramanda \& Husnah, (2014):

Total Debt

Equity Market Value

Book to Market Ratio (External Growth Prospects), Wato (2016):

Company Book Value

Company Market Value

\section{Data Analysis Method}

Test.

Normality Test, Heterokedastisitas Test, Multicollinearity Test, Autocorrelation

\section{Research Model}

The regression equation model in this study is as follows.

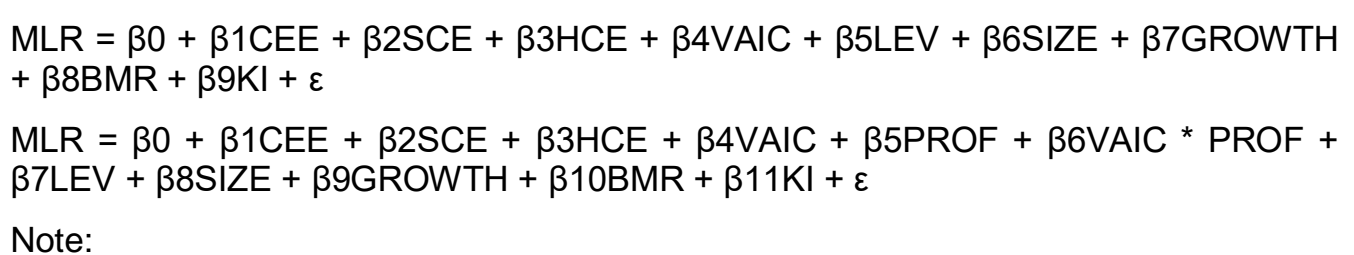

Note:

MLR: Real Profit Management. CEE: Capital Employed Efficiency. SCE: Structural Capital Efficiency. VAIC: Value Added Intellectual Coefficient. HCE: Human Capital Efficiency. PROF: LEV Ownership Profitability: Leverage. SIZE: Company Size. GROWTH: Earnings growth. BMR: Book to Market Ratio. KI: Institutional Ownership. $\varepsilon$ : Standard error.

\section{Hypothesis test}

The hypothesis testing procedure for this study was carried out in three steps, first with the coefficient of determination, then the simultaneous significance test, or better known as the F statistical test, and the test for the significance of individual parameters or the t statistical test. and the coefficient of determination.

\section{EMPIRICAL RESULT AND ANALYSIS}

In Table 1 below, it is known that the dependent variable used in the study is Profit Management has a minimum value of -875.173 , with a maximum value of 119.740 , an average Profit Management of 240 observations of 7.15E with a standard deviation of 86.289. In this study, there are as many as 1 independent variables, Intellectual Capital (VAIC) in Model 1. Whereas in Model 2, the Intellectual Capital (VAIC) variable is broken down into 3 independent variables, namely Capital Employed Efficiency (CEE), Structured Capital Efficiency (SCE), and Human Capital Efficiency (HCE).

The Intellectual Capital variable has a minimum value of 0.624 with a maximum value of 213.237, the average Intellectual Capital of 240 observations is 36.454 with a standard deviation of 34.939. The Capital Employed Efficiency variable in this study had 
a minimum value of 0.017 with a maximum value of 13.867 , the average Capital Employed Efficiency of 240 observations was 1.142 with a standard deviation of 1.110.

Table 1.

Descriptive Statistics

\begin{tabular}{|l|c|c|c|c|c|}
\hline & VAIC & CEE & SCE & HCE & ROA \\
\hline Mean & 36.454 & 1.142 & 0.927 & 34.384 & 7.177 \\
\hline Median & 24.673 & 1.006 & 0.955 & 22.629 & 4.260 \\
\hline Maximum & 213.237 & 13.867 & 0.995 & 210.954 & 72.000 \\
\hline Minimum & 0.624 & 0.017 & -0.278 & 0.782 & -14.000 \\
\hline Std. Dev & 34.939 & 1.110 & 0.113 & 34.542 & 10.318 \\
\hline
\end{tabular}

Note: VAIC; Value Added Intellectual Coefficient, CEE; Capital Employed Efficiency, SCE; Structural Capital Efficiency, HCE: Human Capital Efficiency, ROA:Profitabilitas Source: Processed Data (Eviews 10.0)

\section{Model Selection}

\section{a. Chow Test}

Table 2. Model 1

Estimation Result Model Choising Common Effect vs Individual Effect

\begin{tabular}{|l|c|l|c|}
\hline \multicolumn{1}{|c|}{ Model } & $\begin{array}{c}\text { Probabilita } \\
\text { Chi-square }\end{array}$ & Decision & Notes \\
\hline Without Moderation Variable & 0.000 & Reject $\mathrm{H}_{0}$ & Individual effect \\
\hline With Moderation Variable & 0.000 & Reject $\mathrm{H}_{0}$ & Individual effect \\
\hline
\end{tabular}

Source: Processed Data (Eviews 10.0)

By testing using the Chow test where the null hypothesis $\left(\mathrm{H}_{0}\right)$ is the common effect model, the probability value obtained from Chi-square for model 1 using moderation variables or those that do not use moderation variables is $0.000<0.05$.

Thus the null hypothesis $\left(\mathrm{H}_{0}\right)$ is rejected, so a better model is to use estimation with individual effects, then the next test is to compare fixed effects with random effects where the test uses the Hausman test.

\section{b. Hausman Test}

Table 3. Model 1

Election Estimation Results of Fixed Effect Model vs Random Effect

\begin{tabular}{|c|c|c|c|}
\hline Model & $\begin{array}{c}\text { Probabilita } \\
\text { Chi-square }\end{array}$ & Decision & Notes \\
\hline Without Moderation Variable & 0.015 & Reject $\mathrm{H}_{0}$ & Fixed effect \\
\hline With Moderation Variable & 0.044 & Reject $\mathrm{H}_{0}$ & Fixed effect \\
\hline
\end{tabular}

Source: Processed Data (Eviews 10.0)

By testing using the Hausman test where the null hypothesis $\left(\mathrm{H}_{0}\right)$ is a fixedeffect model, the probability value of Chi-square for model 1 without using the moderation variable is 0.015 and the probability value of Chi-square for model 1 is using moderation variable of 0.044 . Thus the model has a probability value of ChiSquare $<0.05$, so the null hypothesis $\left(\mathrm{H}_{0}\right)$ is rejected, so the better model to use is the estimation with a fixed effect. 
The Accounting Journal of BINANIAGA Vol. 05, No. 01, June 2020

p-ISSN: 2527-4309, e-ISSN: 2580-1481

$5^{\text {th }}$ Accreditation Rating: January 14, 2019 - January 13, 2024

c. Individual Test

Table 4.

Individual Test Results Without Moderation Variable Model 1 and Moderation Variable Model 2

\begin{tabular}{lccccc}
\hline \multirow{2}{*}{ Variable } & \multirow{2}{*}{ Prediction } & \multicolumn{2}{c}{ Model 1 } & \multicolumn{2}{c}{ Model 2 } \\
& & Coeff. & Prob. & Coeff. & Prob. \\
\hline C & & 9.996 & $0.052^{*}$ & 9.288 & $0.016 * *$ \\
CEE & - & -0.628 & 0.144 & -1.028 & 0.264 \\
SCE & - & 6.792 & $0.018 *$ & 5.485 & 0.067 \\
HCE & - & 0.022 & $0.000^{*}$ & 0.030 & $0.008^{* *}$ \\
ROA & + & 0.108 & $0.000^{*}$ & -0.080 & 0.413 \\
CEE*ROA & + & - & - & 0.034 & 0.826 \\
SCE*ROA & + & - & - & 0.324 & 0.331 \\
HCE*ROA & + & - & - & -0.000 & 0.255 \\
INST & - & -0.038 & 0.270 & -0.026 & 0.459 \\
SIZE & - & -0.518 & $0.000^{*}$ & -0.507 & $0.000^{*}$ \\
GROWTH & + & 0.957 & $0.040 *$ & 1.030 & $0.003^{*}$ \\
LEV & - & -0.007 & $0.028 *$ & -0.010 & 0.109 \\
BMR & - & 0.000 & 0.654 & 0.000 & 0.840 \\
\hline Adjusted R & & & 0.977 & & 0.977 \\
F Test & & & $0.000 *$ & & $0.000 *$ \\
\hline
\end{tabular}

Note: * significant 5\%; C; constant, VAIC; Value Added Intellectual Coefficient, ROA; profitability, INST; institutional ownership, size; size, growth, profit growth, LEV; leverage, BMR; book to market ratio, CEE; capital employed efficiency, SCE; structured capital efficiency, HCE; human capital efficiency.

Source: Processed Data (Eviews10.0)

The goodness of fit model 1 without the moderating variable shown by Adj Rsquared produces a coefficient in model 1 that without using a moderation variable of 0.977 , which means the behavior or variation of the independent variables are able to explain the behavior or variation of the dependent variable by $97.741 \%$ and the rest is behavior or variations of other independent variables that affect the dependent variable but are not included in the model. While model 2 which uses 0.977 moderation variable which means the behavior or variations of the independent variables are able to explain the behavior or variations of the dependent variable by $97.702 \%$ and the rest is the behavior or variations of other independent variables that affect the dependent variable but are not included in the model.

$F$ test results in this study showed that the results obtained showed the sig value of model 1 without using moderation variables or with model 2 using moderation variables of $0.000<0.05$ this shows that statistically proven there is at least one independent variable that has an influence on variables dependent.

At the 95 percent confidence level, the variables that have a negative influence on earnings management are SIZE and Leverage (LEV), while Structural Capital Efficiency (SCE), Human Capital Efficiency (HCE), Profitability (ROA), and Profit Growth (GROWTH) have a positive effect towards earnings management. For the variable Capital Employee Efficiency (CEE), Institutional Ownership (INST), and Book to Market Ratio (BMR) statistically do not have a significant effect on earnings management.

The coefficient of the Capital Employee Efficiency (CEE) is -0.628 meaning that if the Capital Employee Efficiency increases by one unit, earnings management will decrease by -0.628 units. The resulting coefficient value in accordance with the hypothesis proposed in this study where the Capital Employee Efficiency has a negative influence on earnings management, then testing the hypothesis is done 
again where the processing results show a sig value of $0.144 / 2>0.05$ (alpha $5 \%$ ) then $\mathrm{Ho}$ is accepted. It was concluded statistically there was no effect of Capital Employee Efficiency on Earnings Management.

While the magnitude of the coefficient of Structural Capital Efficiency (SCE) is 6.792 meaning that if Structural Capital Efficiency increases by one unit, earnings management will increase by 6.792 units. The resulting coefficient value is not in accordance with the hypothesis proposed in this study where Structural Capital Efficiency has a negative influence on earnings management. Therefore, hypothesis testing is not repeated and accepts the null hypothesis. It was concluded statistically there was no effect of Structural Capital Efficiency on Real Profit Management.

The magnitude of the coefficient of Human Capital Efficiency (HCE) is 0.022 meaning that if Human Capital Efficiency increases by one unit, earnings management will increase by 0.022 units. The resulting coefficient value is not in accordance with the hypothesis proposed in this study where Human Capital Efficiency has a negative influence on earnings management. Therefore, hypothesis testing is not repeated and accepts the null hypothesis. It was concluded statistically there was no effect of Human Capital Efficiency on Real Profit Management.

The test is continued by using the Profitability $(R O A)$ variable as a moderating variable or a variable that affects the relationship between Capital Employed Efficiency (CEE), Structured Capital Efficiency (SCE), and Human Capital Efficiency (HCE) on earnings management. The test results can be seen in the table above. The coefficient of the variable Capital Employee Efficiency (CEE) * Profitability (ROA) is 0.034 meaning that if the Capital Employee Efficiency increases by one unit then managerial earnings will increase by 0.034 units moderated by Profitability. Processing results show a sig value of $0.826 / 2>0.05$ (alpha $5 \%$ ) then $\mathrm{Ho}$ is accepted. It was concluded statistically that Profitability was unable to strengthen the effect of Capital Employed Efficiency on Real Profit Management.

Likewise, the magnitude of the coefficient of Structural Capital Efficiency (SCE) * Profitability $(\mathrm{ROA})$ is 0.324 meaning that if Structural Capital Efficiency increases by one unit, managerial earnings will increase by 0.324 units that are moderated by Profitability. Processing results show a sig value of $0.331 / 2>0.05$ (alpha $5 \%$ ) then $\mathrm{Ho}$ is accepted. It was concluded statistically that Profitability was unable to strengthen the effect of Structural Capital Efficiency on Real Profit Management.

The magnitude of the coefficient of Human Capital Efficiency (HCE) * Profitability (ROA) is -0.000 meaning that if Human Capital Efficiency increases by one unit, managerial earnings will decrease by -0.000 units moderated by Profitability. Processing results show a sig value of $0.255 / 2>0.05$ (alpha $5 \%$ ) then $\mathrm{Ho}$ is accepted. It was concluded statistically that profitability was unable to strengthen the effect of Human Capital Efficiency on Real Profit Management.

\section{Discussion}

The results showed that intellectual capital without moderation variables and with moderation variables had no influence on real earnings management, the results of this study support Marzban et al (2014) and Zanjirdar \& Chogha (2012) research. This is due to the fact that some companies in Indonesia use and develop intellectual capital (IC) such as professional staff (CEO, CFO, Director, Manager, etc.) to develop the company with the aim of achieving an expected profit target. In achieving this goal the company has managed earnings management through an operating cash flow approach (CFO) with the aim of maintaining share prices on the capital market.

Likewise, the indicators of Capital Employed Efficiency (CEE), Structured Capital Efficiency (SCE), Human Capital Efficiency (HCE) have no influence on the real earnings management of this study in line with Darabi et al (2012). This might be caused when the Capital Employed Efficiency (CEE) is not running efficiently so that

Sistya Rachmawati. Moderating effect of profitability on intellectual capital and real earnings management 
the customers are not satisfied with the goods and services provided by the company, then they will not have a positive response to the company which can affect the increase in money circulation.

Likewise, Structured Capital Efficiency (SCE) and Human Capital Efficiency (HCE) are not effective, this is because the ability of the organization and its humans can negatively affect the value of the company through a large expenditure burden so as to reduce the value of efficiency. Likewise, profitability is not able to strengthen the effect of Capital Employed Efficiency (CEE), Structured Capital Efficiency (SCE) and Human Capital Efficiency (HCE) on real earnings management. This is due to the high level of profit which can affect the assessment of good management performance. This causes managers not motivated to do real earnings management even does not have a significant influence, while growth control variables, size, and leverage have an influence on real earnings management.

\section{CONCLUSIONS, IMPLICATIONS, AND SUGGESTIONS}

\section{Conclusion}

Based on the description above it can be concluded that Intellectual Capital based on indicators of Capital Employee Efficiency, Structural Capital Efficiency, Human Capital Efficiency (without moderation variables or with moderation variables) has no influence on earnings management. Similarly, profitability is not able to strengthen the effect of Intellectual Capital based on indicators of Capital Employee Efficiency, Structural Capital Efficiency, Human Capital Efficiency on Real Profit Management. While the growth, size and leverage control variables have an influence on real earnings management.

\section{Implication}

The implications of the study are (1) for companies to pay more attention to better intellectual capital in carrying out their functions towards decreasing real earnings management, (2) for regulations, it should improve regulations on profitability so that they can be more functional in improving company performance.

\section{Suggestion}

Based on the discussion above, there are a number of suggestions that might be useful for subsequent research, including: (1) Developing this research by adding control variables and looking for other proxies for profitability. (2) add research samples, not only companies want to invoice, and add years of observation so that research results can be generalized.

\section{REFERENCES}

Darabi, R., Kamran, R. S., \& Ghadiri M. (2012). The Relationship between Intellectual Capital and Brand Equity. Research Journal of Applied Sciences, Engineering and Technology, 4(20), 4192-4199. https://doi.org/10.1177/0258042X15572420

Firer, S., \& Williams, S. M. (2003). Intellectual Capital and Traditional Measures of Corporate Performance. Journal of Intellectual Capital, 4 (3), 348-360. https://doi.org/10.1108/14691930310487806

Galdipour, S., Rahimiyan, F., Etemad, A., \& Panahi, H. (2014). Earnings Management and Intellectual Capital. Jornal of Education and Management Studies, 4 (2), 425-428. 
Hassan, S. U., \& Fapouk, M. A. (2014). Audit Quality and Financial Performance of Quoted Cement Firms in Nigeria. European Journal of Business and Management, 6 (28), 73-82.

Healy, P. M., \& Wahlen, J. M. (1999). A Review of the Earnings Management Literature and Its Implications for Standard Setting. Accounting Horizonz, 13 (4), 365-383. https://doi.org/10.2139/ssrn.156445

Jacub, J. O. S. (2012). Making a Living between Crises and Ceremonies in Tana Toraja. Jurnal Ilmiah Mahasiswa Akuntansi, 1 (4), 96-100. https://doi.org/10.1163/9789004252479

Jensen, M. C., \& Meckling, W. H. (1976). Theory of the Firm: Managerial Behavior, Agency Cost and Ownership Structure. Journal of Financial Economics, 3 (4), 305-360. Retrieved from http://ssrn.com/abstract=94043http://hupress .harvard.edu/catalog/JENTHF.html

Marzban, H. A., Poor, V. K., Kasgari, D. R., \& Amini Asoo. (2014). The Relationship Between Intellectual Capital and Earnings Quality Indicators in Emerging Companies Listed in Tehran Stock Exchange. Indan Journal of Fundamental and Apploed Life Science, 4 (S1), 985-995. https://doi.org/10.1016/j.sbspro.2012.03.227

Mojtahedi, P. (2013). The Impact of Intellectual Capital on Earning Quality: Evidence from Malaysian Firms. Australian Journal of Basic \& Applied Sciences, 7(2), 535540.

Retrieved

from http://search.ebscohost.com/login. aspx? direct=true\&db=a9h\&AN=88895624\&sit $\mathrm{e}=$ ehost-live

Murwaningsari, E. (2014). The influence of intellectual capital towards firm value with independent commissioner and audit committee as moderating variable. International Journal of Engineering, Business and Enterprice Aplication, 1 (9).

Petty, R., \& Guthrie, J. (2000). Intellectual capital literature review: Measurement Reporting and Management. Journal of Intellectual Capital, 1 (2), 155-176.

Pramanda, A., \& Husnah, N. (2014). Pengaruh Intellectual Capital Terhadap Kualitas Laba dengan Corporate Governance Sebagai Variabel Moderasi (Studi di Perusahaan Manufaktur yang Terdaftar di Bursa Efek Indonesia Tahun 20112012. Universitas Indonesia, 1-22.

Pulic, A. (1998). Measuring the Performance of Intellectual Potential in Knowledge Economy. In Presented in 1998 at the 2nd McMaster World Congress on Measuring and Managing Intellectual Capital by the Austrian Team for Intellectual Potential.

Rachmawati, S. (2019). Company Size Moderates the Effect of Real Earning Management and Accrual Earning Management on Value Relevance. Etikonomi, 18 (1), 133-142. https://doi.org/10.15408/etk.v18i1.9381

Roychowdhury, S. (2006). Earnings Management Through Real Activities Manipulation. Journal of Accounting and Economics, 42 (3), 335-370. https://doi.org/10.1016/j.jacceco.2006.01.002

Shapiro, A. C. (1991). Modern Corporate Finance. New York: MacMillan Publishing Company, Maxwell MacMillan International, Editor L.

Sistya Rachmawati. Moderating effect of profitability on intellectual capital and real earnings management 
The Accounting Journal of BINANIAGA Vol. 05, No. 01, June 2020

p-ISSN: 2527-4309, e-ISSN: 2580-1481

$5^{\text {th }}$ Accreditation Rating: January 14, 2019 - January 13, 2024

Sulistiawan, D. (2011). Creative Accounting. Salemba Empat.

Tohir, R., \& Yuyetta, E. N. A. (2013). Pengaruh Struktur Corporate Governance Kualitas Laba dengan Intellectual Capital Disclosure sebagai Variable Intervening. Diponegoro Journal of Accounting, 2 (4), 1-10.

Tong, Y. ., \& Miao, B. (2011). Are Dividends Associated With the Quality of Earnings. Accounting Horizons, 25 (1), 183-205.

Ulum, I. (2009). Intellectual Capital: Konsep dan Kajian Empiris. Yogyakarta: Graha IImu

Wato, T. (2016). Pengaruh Modal Intelektual Terhadap Manajemen Laba Riil dan Future Stock Returns. Media Riset Akuntansi, Auditing Dan Informasi, 16 (2), 107-124.

Zang, A. Y. (2006). Evidence on the Trade-Off between Real Activities Manipulation and Accrual-Based Earnings Management. The Accounting Review, 87 (2), 675703. https://doi.org/10.2308/accr-10196

Zanjirdar, M., \& Chogha, M. (2012). Evaluation of Relationship Between the Intellectual Capital and Earning Quality Indexes in Emerging Economics: Case study of Iran's Financial Market. African Journal of Business Management, 6 (38), 10312-10319. https://doi.org/10.5897/AJBM11.2545 